\title{
Chimeric virus-like particles presenting common neutralizing epitopes of enterovirus 71
}

\author{
Bo Wang ${ }^{*}$, Qingwei Liu, Jinping Shi, Yicun Cai, Zhong Huang \\ From Institut Pasteur International Network Annual Scientific Meeting \\ Hong Kong. 22-23 November 2010
}

To develop an effective vaccine against multiple genotypes of enterovirus 71 (EV71), we generated chimeric virus-like particles (VLPs) repetitively displaying the common neutralizing epitopes of EV71 and evaluated their immunogenicities in mice. The two conserved epitopes, encompassing amino acids 163-177 and 208-222 of VP1 of EV71, were fused to hepatitis B core antigen ( $\mathrm{HBcAg})$ and expressed in E.coli. The resulting fusion proteins were found to assemble into chimeric VLPs. Both unmodified HBcAg and chimeric VLPs induced $\mathrm{HBcAg}$-specific antibody responses in mice, however, only chimeric VLP-immunized sera possessed EV71 epitope-specific IgG antibodies and efficiently neutralized different EV71 strains. Collectively, our results indicate that the chimeric VLP is capable of eliciting broadly neutralizing antibody responses and is therefore a promising EV71 vaccine candidate.

Published: 10 January 2011

doi:10.1186/1753-6561-5-S1-P29

Cite this article as: Wang et al:: Chimeric virus-like particles presenting common neutralizing epitopes of enterovirus 71. BMC Proceedings 2011 5(Suppl 1):P29.
Key laboratory of Molecular Virology \& Immunology, Institut Pasteur of Shanghai, Chinese Academy of Sciences, Shanghai 200025, PR China
Submit your next manuscript to BioMed Central and take full advantage of:

- Convenient online submission

- Thorough peer review

- No space constraints or color figure charges

- Immediate publication on acceptance

- Inclusion in PubMed, CAS, Scopus and Google Scholar

- Research which is freely available for redistribution

\section{Biomed Central}

